$\underline{\text { Review Article }}$

\title{
Imatinib in Chronic Myeloid Leukemia: an Overview
}

Tomasz Sacha

Department of Hematology, Collegium Medicum, Jagiellonian University, Cracow, Poland.

Correspondence to: Dr. Tomasz Sacha , Department of Hematology, Collegium Medicum, Jagiellonian University, Cracow, Poland. E-mail: sachatom@gmail.com

Competing interests: The authors have declared that no competing interests exist.

Published: January 2, 2014

Received: November 25, 2013

Accepted: December 2, 2013

Citation: Mediterr J Hematol Infect Dis 2014, 6(1): e2014007, DOI: 10.4084/MJHID.2014.007

This article is available from: http://www.mjhid.org/article/view/12506

This is an Open Access article distributed under the terms of the Creative Commons Attribution License (http://creativecommons.org/licenses/by/2.0), which permits unrestricted use, distribution, and reproduction in any medium, provided the original work is properly cited.

Abstract. Imatinib was the first signal transduction inhibitor (STI), used in a clinical setting. It prevents a BCR-ABL protein from exerting its role in the oncogenic pathway in chronic myeloid leukemia (CML). Imatinib directly inhibits the constitutive tyrosine kinase activity. Imatinib binds to BCR-ABL kinase domain by preventing the transfer of a phosphate group to tyrosine on the protein substrate and the subsequent activation of phosphorylated protein. As the result, the transmission of proliferative signals to the nucleus is blocked and leukemic cell apoptosis is induced. The FDA has approved imatinib as first-line treatment for newly diagnosed CML in December 2002 following an International Randomized Study (IRIS), initiated in June 2000, comparing imatinib at a single daily dose $400 \mathrm{mg}$ to IFN alpha plus cytarabine in newly diagnosed patients with CML in CP . Results from this study show the outstanding effectiveness of imatinib and its superiority with respect to the rates of complete hematological response (CHR), major and complete cytogenetic response (MCyR, CCyR). Patients randomized to imatinib arm at 8 - year data cut off continue to have a durable hematologic and cytogenetic responses, low progression rates to $\mathrm{AP}$ or $\mathrm{BC}$, and remarkable survival outcomes. An overall survival (OS) rate is $85 \%$ for patients receiving imatinib (93\% when only CML-related deaths and those prior to stem cell transplantation are considered). The results have been confirmed in the last years by several groups. According these cumulative results the rates of CCyR achieved after one year of therapy with imatinib at standard dose ranged from $49 \%$ to $77 \%$, and the proportion of patients who achieved major molecular response (MMR) after one year ranged between $18 \%$ and $58 \%$. Discontinuation of imatinib has been also tried in patients in MMR, a molecular relapse occurs in about one third of patients, generally within 6 months from imatinib cessation.

Introduction. Imatinib was the first signal transduction inhibitor (STI), used in a clinical setting. It prevents a BCR-ABL protein from exerting its role in the oncogenic pathway in chronic myeloid leukemia
(CML). Imatinib directly inhibits the constitutive tyrosine kinase activity, which results in the modification of the function of various genes involved in the control of the cell cycle, cell adhesion, cytoskeleton organization and finally in the apoptotic 
death of $\mathrm{Ph}(+)$ cells. ${ }^{1}$

Imatinib binds to BCR-ABL kinase domain, which is in an inactive conformation in a pocket reserved for the ATP binding site, thus preventing the transfer of a phosphate group to tyrosine on the protein substrate and the subsequent activation of phosphorylated protein. As the result, the transmission of proliferative signals to the nucleus is blocked and leukemic cell apoptosis is induced. ${ }^{2}$ Preclinial in vitro studies showed that imatinib is a tyrosine kinase inhibitor (TKI) of ABL kinase and its active derivatives: viral Abelson nonreceptor protein tyrosine kinase (v-ABL), BCR$A B L,{ }^{3,4}$ TEL-ABL, ${ }^{5}$ platelet-derived growth factor receptor (PDGFR) and Steel factor receptor (c-KIT) kinases. ${ }^{6}$ Imatinib exhibits high level of selectivity. Its activity against the above protein kinases is similar with IC50 values in the range of $0.025 \mathrm{M}$ for protein autophosphorylation and is at least 100 -fold lower than for a large number of other tyrosine and serine/threonine kinases. ${ }^{6}$

Pharmacokinetics of Imatinib. Pharmacokinetics of imatinib is characterized by rapid and complete oral bioavailability (98\%) and a proportional dose-exposure relationship. ${ }^{18,19}$ There is no significant interaction of imatinib with food intake. Its terminal half-life is approximately 18 hours, allowing for once-daily dosing. ${ }^{18,19}$ The median peak plasma concentrations at steady state of imatinib administered orally once a day at a dose of $400 \mathrm{mg}$ and median trough levels are 5.4 $\mathrm{M}$, and $1.43 \mathrm{M}$ respectively. ${ }^{7}$ Imatinib is metabolized by the cytochrome P450 system. CYP3A4 is the major isoenzyme responsible for imatinib metabolism, although CYP1A2, CYP2D6, CYP2C9, and CYP2C19 also contribute to a minor extent. ${ }^{18,19}$ The activity of CYP enzyme exhibits intrinsic variability, which could be the cause of high interpatient unevenness in imatinib exposure. ${ }^{18,19}$ Drugs that are inhibitors or inductors of the CYP3A4 isoenzyme have been shown to alter imatinib pharmacokinetic activity. ${ }^{20}$

Efficacy of Imatinib. Phase I trials: The first phase I trial was initiated in June 1998 and enrolled patients suffering from CML in chronic phase (CP) who were resistant to or intolerant of interferon alpha (IFN alpha). Almost all patients (98\%) treated with at least $300 \mathrm{mg}$ imatinib per day achieved complete hematological response (CHR). Major and complete cytogenetic response (MCyR, CCyR) were obtained by $31 \%$ and $13 \%$ of patients respectively. Of note, the responses were durable, only 2 relapses (out of 53 patients) were noted after a median follow-up of 265 days. $^{8}$ Based on these results, the protocol was expanded and included 58 patients in blast crisis (BC) or with Ph-positive acute lymphoblastic leukemia
$(\mathrm{Ph}+\mathrm{ALL})$. Hematological responses to minimal dose of imatinib in this cohort (300 mg daily) were obtained in $55 \%$ and $70 \%$ of patients with myeloid, and lymphoid blast crisis respectively, including four CHR in each group. Twelve percent of patients achieved MCyR and 8\% CCyR. Patients treated in BC unlike patients treated in the $\mathrm{CP}$ relapsed frequently after initiating imatinib therapy. Approximately $50 \%$ of responders with myeloid phenotype and all but one responder with lymphoid phenotype relapsed between 42 and 193 days of imatinib treatment (Druker et al., 2001b). Patients in accelerated phase (AP) had not been studied in the phase I protocols.

Phase II trials: Three international multicenter phase II trials were initiated in 1999. The study population included patients with CML in myeloid BC, relapsed $\mathrm{Ph}+\mathrm{ALL}, \mathrm{CML}$ in AP, and patients who were resistant to IFN alpha. The results achieved in patients suffering from BC with myeloid phenotype largely confirmed the results obtained in the phase I study. ${ }^{9}$ In contrast to patients with myeloid type of disease, none of patients treated for lymphoid blast crisis and for relapsed $\mathrm{Ph}+\mathrm{ALL}$ had durable response to imatinib. ${ }^{10}$ The results of patients treated for AP fall between those observed in myeloid $\mathrm{BC}$ and $\mathrm{CP}$ with the 1-year survival achieved in $74 \%$ patients. A retrospective comparison between two dose cohorts (400 mg and $600 \mathrm{mg}$ daily) showed a significantly longer time to progression and overall survival for the $600 \mathrm{mg}$ cohort. ${ }^{11}$ Based on these studies the recommended daily dose for patients in advanced phases of CML was set at $600 \mathrm{mg}$ daily, ${ }^{9,11}$ and the recommendation of increasing the imatinib dose to 600 and $800 \mathrm{mg}$ daily was rapidly extended also to patients in CP with unsatisfactory response to $400 \mathrm{mg}$ daily, or response loss. The patients suffering from CML in CP hematologically or cytogenetically resistant or refractory, or intolerant of IFN alpha were the largest group studied within phase II trials. Ninety five percent of all patients achieved CHR; CCyR and MCyR were seen in $41 \%$ and $60 \%$ of patients respectively, and the progression-free survival rate at 18 months was $89 \%{ }^{6}$ Phase III trials: An International Randomized Study of Interferon and STI571 (IRIS) comparing imatinib at a single daily dose $400 \mathrm{mg}$ to IFN alpha plus cytarabine in newly diagnosed patients with CML in CP was initiated in June 2000. Results from this study show the outstanding effectiveness of imatinib and its superiority with respect to the rates of CHR, MCyR and CCyR. At 18 months, the rate of CCyR in patients treated with imatinib was $76 \%$ versus $15 \%$ for patients treated with IFN alpha plus cytarabine $(P<.001)$. Importantly, the rate of progression to AP or BC at 18 months was significantly reduced in patients randomized to imatinib arm. ${ }^{12}$ Based on these results, 
the FDA has approved imatinib as first-line treatment for newly diagnosed CML in December 2002. At 8 years of follow-up, $45 \%$ of patients had discontinued treatment due to adverse events (AEs)/safety (6\%), unsatisfactory therapeutic outcome (16\%), stem cell transplantation (SCT) (3\%), death (3\%) or other reasons $(17 \%$ for withdrawal or lack of renewal of consent and miscellaneous). Patients randomized to imatinib arm at 8 - year data cut off continue to have a durable hematologic and cytogenetic responses, low progression rates to $\mathrm{AP}$ or $\mathrm{BC}$, and remarkable survival outcomes. ${ }^{12-15}$ An overall survival (OS) rate is $85 \%$ for patients receiving imatinib (93\% when only CMLrelated deaths and those prior to stem cell transplantation are considered), with the annual rates of progression to AP or BC in year 4 to 8 after imatinib therapy onset are: $0.9 \%, 0.5 \%, 0 \%, 0 \%$, and $0.4 \%$, respectively. Progression to AP or BC was noted only in $3 \%$ of patients who achieved CCyR, and in none of patients who achieved major molecular response (MMR, < $0.1 \%$ BCR-ABL/control gene ratio on international scale) at 12 months of therapy. ${ }^{16}$ The patients treated with imatinib who had at 18 months $\mathrm{a} \geq$ $3 \log$ reduction in the level of BCR-ABL transcripts compared with a standardized baseline had a minimal risk of disease progression over the subsequent 12 months. ${ }^{17}$

Table. Efficacy of imatinib in front line treatment in major clinical trials

\begin{tabular}{|c|c|c|c|c|c|}
\hline Trial & Studied population & $\begin{array}{l}\text { Imatinib } \\
\text { dosage }\end{array}$ & $\begin{array}{c}\text { Complete } \\
\text { cytogenetic } \\
\text { response } \\
\text { (CCyR) } \\
\text { rate [\%] }\end{array}$ & $\begin{array}{c}\text { Major } \\
\text { molecular } \\
\text { response } \\
\text { (MMR) } \\
\text { rate [\%] }\end{array}$ & $\begin{array}{l}\text { Estimated } \\
\text { progression-free survival } \\
(\text { PFS) /, overall survival } \\
\text { (OS) }\end{array}$ \\
\hline \multicolumn{6}{|c|}{ Phase I trials } \\
\hline $\begin{array}{l}\text { [Druker et al. } \\
\text { 2001a] }\end{array}$ & $\begin{array}{l}\text { CML patients in chronic phase (CP) } \\
\text { resistant to or intolerant of IFN alpha }\end{array}$ & $\begin{array}{l}\geq 300 \\
\mathrm{mg} / \mathrm{d}\end{array}$ & $13 \%$ & NR & NR \\
\hline $\begin{array}{l}\text { [Druker et al. } \\
\text { 2001b] }\end{array}$ & $\begin{array}{l}\text { CML patients in blastic phase - myeloid } \\
\text { CML patients in blastic phase - lymphoid }\end{array}$ & $\begin{array}{l}300- \\
1000 \\
\mathrm{mg} / \mathrm{d}\end{array}$ & $\begin{array}{l}14 \% \\
14 \%\end{array}$ & $\begin{array}{l}\text { NR } \\
\text { NR }\end{array}$ & $\begin{array}{l}\text { PFS: } 84 \text { days / OS: NR } \\
\text { PFS: } 58 \text { days / OS: NR }\end{array}$ \\
\hline \multicolumn{6}{|c|}{ Phase II trials } \\
\hline $\begin{array}{l}\text { [Sawyers et al. } \\
2002 \text { ] }\end{array}$ & CML patients in blastic phase - myeloid & $\begin{array}{l}400-600 \\
\mathrm{mg} / \mathrm{d}\end{array}$ & $7 \%$ & NR & $\begin{array}{l}\text { Median response time } 10 \\
\text { months / median survival } \\
\text { time } 6,9 \text { months }\end{array}$ \\
\hline $\begin{array}{l}\text { [Ottmann et al. } \\
\text { 2002] }\end{array}$ & CML patients in blastic phase - lymphoid & $\begin{array}{c}400-600 \\
\mathrm{mg} / \mathrm{d}\end{array}$ & $17 \%$ & NR & 2,2 / 4,9 months \\
\hline $\begin{array}{l}\text { [Deininger et al. } \\
\text { 2003] }\end{array}$ & $\begin{array}{l}\text { CML patients in CP resistant or } \\
\text { refractory, or intolerant of IFN alpha }\end{array}$ & $\begin{array}{c}400 \\
\mathrm{mg} / \mathrm{d}\end{array}$ & $41 \%$ & NR & $\begin{array}{c}18 \text { month PFS } 89 \% / 9,2 \\
\text { months }\end{array}$ \\
\hline \multicolumn{6}{|c|}{ Phase III trials } \\
\hline $\begin{array}{l}\text { IRIS study } \\
\text { [Deininger et al. } \\
\text { 2009] }\end{array}$ & CML patients in CP de novo & $\begin{array}{l}400 \\
\mathrm{mg} / \mathrm{d}\end{array}$ & $\begin{array}{l}\text { At } 8 \text { years: } \\
\quad 83 \%\end{array}$ & $\begin{array}{l}\text { At } 8 \text { years: } \\
\quad 86 \%\end{array}$ & $\begin{array}{l}\text { At } 8 \text { year: PFS:92\% / OS: } \\
\text { 89\%; 93\% if only CML - } \\
\text { related deaths considered }\end{array}$ \\
\hline $\begin{array}{l}\text { PETHEMA } \\
\text { [Cervantes et al. } \\
\text { 2010] } \\
\end{array}$ & CML patients in CP de novo & $\begin{array}{l}400 \\
\mathrm{mg} / \mathrm{d}\end{array}$ & $\begin{array}{c}\text { At } 3 \text { years } \\
\text { (ITT) } \\
78,8 \% \\
\end{array}$ & $\begin{array}{l}\text { At } 3 \text { years } \\
\text { (ITT) } 63 \%\end{array}$ & $\begin{array}{c}\text { At } 5 \text { years PFS: } 94,3 \% / \text { OS: } \\
97,5 \%\end{array}$ \\
\hline $\begin{array}{l}\text { SPIRIT } \\
\text { [Preudhomme et al. } \\
\text { 2010] }\end{array}$ & CML patients in CP de novo & $\begin{array}{l}400 \\
\mathrm{mg} / \mathrm{d}\end{array}$ & $\begin{array}{l}\text { At } 12 \\
\text { months } \\
58 \%\end{array}$ & $\begin{array}{l}\text { At } 12 / 24 \\
\text { months: } \\
38 \% / 43 \%\end{array}$ & At 2 years PFS: 97,5\% \\
\hline $\begin{array}{l}\text { GIMEMA } \\
\text { [Gugliotta et al. } \\
\text { 2011] }\end{array}$ & CML patients in CP de novo & $\begin{array}{c}400 \\
\mathrm{mg} / \mathrm{d}\end{array}$ & $\begin{array}{l}\text { At } 52 \\
\text { months } \\
87 \%-88 \%\end{array}$ & $\begin{array}{l}\text { At } 52 \\
\text { months } \\
85 \%\end{array}$ & $\begin{array}{c}\text { At } 6 \text { years PFS:75/90\% / } \\
\text { OS: } 78 / 92 \% \\
(<65 / \geq 65 \text { year-old } \\
\text { pts.resp.) }\end{array}$ \\
\hline $\begin{array}{l}\text { CAMELIA } \\
\text { [Faber et al. 2013] }\end{array}$ & CML patients in CP de novo & $\begin{array}{l}400 \\
\mathrm{mg} / \mathrm{d}\end{array}$ & $83 \%$ & NR & $\begin{array}{l}\text { At } 5 \text { years PFS:96\%/OS: } \\
90 \% \\
\end{array}$ \\
\hline $\begin{array}{l}\text { German Study } \\
\text { Group IV } \\
\text { [Hehlmann et al. } \\
\text { 2011] }\end{array}$ & CML patients in CP de novo & $\begin{array}{c}400 \\
\mathrm{mg} / \mathrm{d}\end{array}$ & $\begin{array}{l}\text { At } 3 \text { years } \\
85,2 \%\end{array}$ & $\begin{array}{l}\text { At } 3 \text { years } \\
79 \%\end{array}$ & $\begin{array}{c}\text { At } 3 \text { years PFS: } 94-99 \% / \\
\text { OS: } 93-99 \% \text { (for }<1 \% \text { and } \geq \\
1 \% \text { of BCR-ABL resp.) }\end{array}$ \\
\hline $\begin{array}{l}\text { DASISION [Saglio } \\
\text { et al. 2010] }\end{array}$ & CML patients in CP de novo & $\begin{array}{c}400 \\
\mathrm{mg} / \mathrm{d}\end{array}$ & $\begin{array}{l}\text { At } 18 \\
\text { months } \\
70 \%\end{array}$ & $\begin{array}{l}\text { At any time } \\
\quad 41 \%\end{array}$ & PFS: 93,7\% / OS: 97,9\% \\
\hline $\begin{array}{l}\text { ENESTnd } \\
\text { [Kantarjian et al. } \\
\text { 2010] } \\
\end{array}$ & CML patients in CP de novo & $\begin{array}{c}400 \\
\mathrm{mg} / \mathrm{d}\end{array}$ & $\begin{array}{l}\text { At } 12 \\
\text { months } \\
65 \%\end{array}$ & $\begin{array}{l}\text { At any time } \\
\quad 44 \%\end{array}$ & PFS 95,2\% / OS: 96,4\% \\
\hline
\end{tabular}




\begin{tabular}{|c|c|c|c|c|c|}
\hline \multicolumn{6}{|c|}{ Combinations of IM and high IM dose } \\
\hline $\begin{array}{l}\text { [Kantarjian et al. } \\
\text { 2004] }\end{array}$ & CML patients in CP de novo & $\begin{array}{l}800 \\
\mathrm{mg} / \mathrm{d}\end{array}$ & $90 \%$ & $\begin{array}{l}63 \%(\mathrm{BCR}- \\
\mathrm{ABL} / \mathrm{ABL} \\
\text { ratio } \\
<0,05 \%) \\
\end{array}$ & $\begin{array}{c}\text { At } 15 \text { months PFS: } 98 \% \text { / } \\
\text { OS: } 98,3 \% \%\end{array}$ \\
\hline $\begin{array}{l}\text { European } \\
\text { LeukemiaNet study } \\
\text { [Baccarani et al. } \\
\text { 2009] }\end{array}$ & CML patients in CP de novo & $\begin{array}{c}400 \\
\mathrm{mg} / \mathrm{d}\end{array}$ & $\begin{array}{l}\text { At } 12 \\
\text { months } \\
58 \% \\
\text { At } 12 \\
\text { months } \\
64 \%\end{array}$ & $\begin{array}{l}\text { At } 12 \\
\text { months } \\
33,3 \% \\
\text { At } 12 \\
\text { months } \\
39,8 \%\end{array}$ & $\begin{array}{l}\text { At } 3 \text { years PFS: } 86 \% \text { / OS: } \\
\qquad 84 \% \\
\text { At } 3 \text { years PFS: } 88 \% \text { / OS: } \\
\qquad 91 \%\end{array}$ \\
\hline $\begin{array}{l}\text { [Andreas et al. } \\
\text { 2008] } \\
\text { [Andreas et al. } \\
\text { 2008] }\end{array}$ & $\begin{array}{l}\text { CML patients in CP de novo } \\
\text { CML patients in CP de novo }\end{array}$ & $\begin{array}{c}400 \\
\mathrm{mg} / \mathrm{d}\end{array}$ & $\begin{array}{c}\text { At } 6 \\
\text { months } \\
20 \% \\
\\
44 \% \\
\text { (differences } \\
\text { not } \\
\text { significant } \\
\text { at } 12 \\
\text { months) } \\
\end{array}$ & $\begin{array}{c}\text { At } 6 \\
\text { months } \\
7 \% \\
\\
20 \% \\
\text { (differences } \\
\text { not } \\
\text { significant } \\
\text { at } 12 \\
\text { months) } \\
\end{array}$ & NR \\
\hline $\begin{array}{l}\text { TOPS study } \\
\text { [Cortes et al. 2008] }\end{array}$ & CML patients in CP de novo & $\begin{array}{c}400 \\
\mathrm{mg} / \mathrm{d} \\
\\
800 \\
\mathrm{mg} / \mathrm{d}\end{array}$ & $\begin{array}{c}\text { At } 12 \\
\text { months } \\
66 \% \\
66 \%\end{array}$ & $\begin{array}{c}\text { At } 12 \\
\text { months } \\
40,1 \% \\
46,4 \%\end{array}$ & $\begin{array}{c}\text { AT } 18 \text { months PFS: } 95 \% \text { / } \\
\text { OS: } 98,7 \% \\
\text { PFS: } 97 \% \text { / OS: } 98,2 \%\end{array}$ \\
\hline $\begin{array}{l}\text { German Study } \\
\text { Group IV } \\
\text { [Hehlmann et al. } \\
2011]\end{array}$ & CML patients in CP de novo & $\begin{array}{c}800 \\
\mathrm{mg} / \mathrm{d} \\
\\
\\
\\
400 \\
\mathrm{mg} / \mathrm{d}+ \\
\text { IFN } \\
\text { alpha } \\
\end{array}$ & $\begin{array}{l}\text { At } 3 \text { years } \\
85,2 \% \\
\\
78,5 \%\end{array}$ & $\begin{array}{l}\text { At } 3 \text { years } \\
79 \% \\
\\
\\
63 \%\end{array}$ & $\begin{array}{c}\text { At } 3 \text { years PFS: } 94 \% / 99 \% \text { / } \\
\text { OS: } 93 / 99 \% \text { (for }<1 \% \text { and } \geq \\
\text { 1\% of BCR-ABL resp.) } \\
\text { At } 2 \text { years PFS: } 80,3 \% / \text { at } 5 \\
\text { years OS: } 91 \%\end{array}$ \\
\hline $\begin{array}{l}\text { SPIRIT } \\
\text { [Preudhomme et al. } \\
\text { 2010] }\end{array}$ & CML patients in CP de novo & $\begin{array}{c}600 \\
\mathrm{mg} / \mathrm{d} \\
\\
\\
400 \\
\mathrm{mg} / \mathrm{d}+ \\
\text { IFN } \\
\text { alpha } \\
\end{array}$ & $\begin{array}{l}\text { At } 12 \\
\text { months } \\
65 \% \\
66 \%\end{array}$ & $\begin{array}{l}\text { At } 12 / 24 \\
\text { months } \\
49 \% / 53 \% \\
57 \% / 64 \%\end{array}$ & $\begin{array}{l}\text { At } 2 \text { years PFS: } 96,9 \% \text { / OS } \\
\text { NR } \\
\text { At } 2 \text { years PFS: } 96,8 \% \text { / OS } \\
\text { NR }\end{array}$ \\
\hline $\begin{array}{l}\text { Nordic trial } \\
\text { [Simonsson et al. } \\
\text { 2011] }\end{array}$ & CML patients in CP de novo & $\begin{array}{c}400 \\
\mathrm{mg} / \mathrm{d} \\
\\
\\
400 \\
\mathrm{mg} / \mathrm{d} \\
+\mathrm{PegIFN} \\
\end{array}$ & $\begin{array}{l}\text { At } 52 \\
\text { weeks } \\
83,9 \% \\
91,1 \%\end{array}$ & $\begin{array}{l}\text { At } 12 \\
\text { months } \\
54 \% \\
82 \%\end{array}$ & $\begin{array}{l}\text { NR } \\
\text { NR }\end{array}$ \\
\hline $\begin{array}{l}\text { MDACC study } \\
\text { [Cortes et al. 2011] }\end{array}$ & CML patients in CP de novo & $\begin{array}{c}800 \\
\mathrm{mg} / \mathrm{d} \\
\\
800 \\
\mathrm{mg} / \mathrm{d} \\
+ \text { PegIFN } \\
\end{array}$ & $\begin{array}{l}\text { At } 12 \\
\text { months } \\
87 \% \\
90 \%\end{array}$ & $\begin{array}{l}\text { At } 12 \\
\text { months } \\
77 \% \\
77 \%\end{array}$ & $\begin{array}{l}\text { NR } \\
\text { NR }\end{array}$ \\
\hline
\end{tabular}

NR - not reported 
The achievement of an MMR continued to be associated with an improved outcome at 5-year, with estimated rates without progression to AP/BC of $100 \%$, 98\%, and $87 \%$ for patients achieving CCyR and MMR, CCyR without MMR, and no CCyR, respectively. ${ }^{13}$ The best observed MMR rate with the 8-year follow-up of IRIS trial is $86 \%$. The results of imatinib first line based on analysis of data derived from clinical trials and registries have been reported in the last three years by several groups (PETHEMA, SPIRIT, GIMEMA, CAMELIA, German Study Group IV, and others.). ${ }^{21-30}$ The rates of CCyR achieved after one year of therapy with imatinib at standard dose ranged from $49 \%$ to $77 \%$, and the proportion of patients who achieved MMR after one year ranged between $18 \%$ and $58 \%$.

The Efficacy of Imatinib at Higher Dose; Combinations with other Agents. Preclinical data and some observations from single - arm studies suggested that higher dosages of imatinib could be more effective than standard $400 \mathrm{mg}$ once daily dose, and may provide a better disease control. The amplification of the BCR-ABL gene or overexpression of bcr-abl protein kinase are two known mechanisms of relative resistance to imatinib ${ }^{34-36}$ which could be overcome by dosages of $600 \mathrm{mg}$ or $800 \mathrm{mg}$ daily. However the initial reports that high dose imatinib treatment results in better, and achieved more rapidly responses than during standard dose imatinib remain controversial. Kantarjian et al. reports that compared with standarddose imatinib, the dose of $800 \mathrm{mg}$ daily was associated with achievement of significantly better rates of CCyR, major (defined as BCR-ABL/ABL ratio $\leq 0.05 \%$ ), and complete (BCR-ABL/ABL negative) molecular responses. Transformation-free survival in this cohort of patients was significantly better with high-dose imatinib. Similar frequency of common adverse events with that seen with standard-dose imatinib were reported. The most common causes for dose reduction were myelosuppression. ${ }^{37}$ The German Study Group IV randomized trial compared imatinib 800 mg daily with standard dose imatinib +/- IFN in newly diagnosed CML patients in CP with regard to molecular response at 12 months and survival. Of 218 patients receiving imatinib $800 \mathrm{mg}$ and evaluable for dosage at 12 months $45.9 \%$ received more than $700 \mathrm{mg} /$ day. The cumulative incidences of CCyR and MMR at 12 months were significantly higher in imatinib $800 \mathrm{mg}$ arm and lower and comparable in imatinib $400 \mathrm{mg}$ and imatinib 400 +IFN alpha arms. MMR at 12 months have been reached faster with imatinib $800 \mathrm{mg}$, but this faster response did not translate into a better OS or progression-free survival (PFS). ${ }^{25}$ A Randomized European LekemiaNet Study addressed the issue of comparison of imatinib $400 \mathrm{mg}$ and $800 \mathrm{mg}$ daily in the front-line treatment of high-risk, Philadelphia- positive CML patients. 216 high risk patients according to the Sokal index were randomized into a group treated for at least 1 year front - line with imatinib at a dose of $800 \mathrm{mg}$ daily or $400 \mathrm{mg}$ daily. At 12 months the rate of CCyR (the primary endpoint) was better in the high-dose arm than in the standard-dose arm but the difference was not statistically significant. Importantly, the number of failures and the number of patients who discontinued treatment for any reasons were not different in those two arms. The proportion of MMR at any time point was slightly but nonsignificantly higher in the high-dose arm than in the standard-dose arm. This large, prospective, intention-to-treat, randomized study on therapy for high risk patients with CML failed to demonstrate a benefit of imatinib administered at a higher dose for the primary end point, as well as for any other measure of efficacy, toxicity, and compliance. $^{38}$ In the other study of imatinib $400 \mathrm{mg}$ versus $800 \mathrm{mg}$ daily in 227 patients in late chronic phase who were resistant or intolerant to IFN alpha imatinib $800 \mathrm{mg}$ daily was associated with a higher CCyR rate at 6 months but not at 12 months. ${ }^{39}$ The MMR rate at 12 months was the primary end point of another study of 476 patients, any risk, who were randomized to receive front-line imatinib at a dose of $800 \mathrm{mg}$ or $400 \mathrm{mg}$ daily. ${ }^{40}$ The difference in the MMR rate at 12 months between $400 \mathrm{mg}$ and $800 \mathrm{mg}$ arm was not significant. These studies does not support the wide use of imatinib at higher dosis front-line in all patients suffering from CML.

Combination of imatinib with low dose arabinosyl cytosine have been tested in two randomized trials, but none have demonstrated a superiority versus therapy with imatinib alone. ${ }^{41,22}$ The German CML Study IV was designed to compare in a randomized fashion standard imatinib vs. imatinib + IFN alpha vs. imatinib + low dose araC vs. imatinib after IFN (for low- and intermediate-risk patients) or vs. imatinib $800 \mathrm{mg}$ (for high-risk patients). At 3 years, the cumulative incidence of CHR, MCyR, CCyR and of MMR were comparable for primary imatinib therapies. ${ }^{41}$ A French SPIRIT randomized study for untreated chronic-phase CML patients compared efficacy of imatinib alone at a dose of $400 \mathrm{mg}$ daily, imatinib (400 mg daily) plus cytarabine (20 mg per square meter of body-surface area per day on days 15 through 28 of each 28-day cycle) or pegylated interferon (peginterferon) alfa-2a (90 $\mu$ g weekly), or imatinib alone at a dose of $600 \mathrm{mg}$ daily. ${ }^{22}$ At 12 months, the rates of CCyR were similar among the four groups. Combination of imatinib and low dose arabinosyl cytosine was not superior to imatinib alone in any measure of efficacy. Patients treated with combination of imatinib and peginterferon alfa-2a achieved significantly better rate (30\%, 38\%) of a superior molecular response (corresponding to MR 4) 
than patients receiving $400 \mathrm{mg}$ of imatinib alone (14\%, $21 \%)$ at 1 , and at 2 year respectively $(\mathrm{P}=0.001)$. During the first year of the trial, however, $39 \%$ of the patients discontinued cytarabine, and $45 \%$ discontinued peginterferon alfa-2a, both predominantly due to a toxicity. A lower dose of peginterferon alfa-2a (e.g., 45 $\mu$ g per week) enhanced the tolerability while retaining the antileukemic efficacy. The rate of grade 3 to 4 hematologic toxicity has been reduced from $54 \%$ to $27 \%$, and the proportion of patients who discontinued peginterferon alfa-2a before 6 months decreased from $40 \%$ to $10 \%$. By 12 months, the cumulative MR4 for the subgroup treated with imatinib at a dose of $400 \mathrm{mg}$ and the PegIFN90 vs imatinib of 400-mg and PegIFN45 were $25 \%$ and $28 \%$ respectively. ${ }^{42}$ The main phase of CML German Study IV compared monotherapy with imatinib $400 \mathrm{mg} / \mathrm{d}$ versus imatinib $400 \mathrm{mg} / \mathrm{d}$ combined with nonpegylated IFN-alpha given at an initial dose of 1.5 mill.U three times per week and increased up to 3 mill.U three times per week, according to tolerability versus imatinib 800 $\mathrm{mg} / \mathrm{d}$. At 12 months the rates of MMR which was the first primary end point were similar in the monotherapy imatinib $400 \mathrm{mg} / \mathrm{d}$ arm (44\% [95\% CI, $37 \%$ to $50 \%]$ ) and in the imatinib $400 \mathrm{mg} / \mathrm{d}$ combined with IFN-alpha $46 \%$ [95\% CI, $40 \%$ to $52 \%$ ] arm and inferior to imatinib $800 \mathrm{mg} / \mathrm{d} \mathrm{arm} .{ }^{25}$ In the Nordic trial newly diagnosed chronic-phase CML patients with a low or intermediate Sokal risk score were randomized either to group treated with a combination of pegylated IFN-alpha 2b (Peg-IFN-alpha 2b) at a dose of $50 \mu \mathrm{g}$ weekly and imatinib $400 \mathrm{mg}$ daily or with imatinib 400 mg daily as a monotherapy. The MMR rate at 12 months was significantly higher in the combination arm (82\%) compared with the imatinib monotherapy arm (54\%; intention-to-treat, $P=.002)$. In the combination arm, however, $61 \%$ of patients discontinued Peg-IFN-alpha 2b, most because of toxicity. ${ }^{43}$ In the MD Anderson Cancer Center (MDACC) trial patients were randomized to receive imatinib $400 \mathrm{mg}$ twice daily, and combination of imatinib $800 \mathrm{mg} / \mathrm{d}$ with pegylated rIFN-alpha $2 \mathrm{~b} 0.5$ $\mu \mathrm{g} / \mathrm{kg}$ weekly. The MMR and the CCyR rates were comparable in both arms. ${ }^{44}$ None of these combination studies has demonstrated a superior PFS or OS for patients who received combined treatment.

Studies on Cessation of Imatinib. Allogeneic haematopoietic stem cell transplantation (Allo-HSCT) has been and is still considered as the sole treatment able to cure CML. As a result of allo-HSCT a long period of time free from cytogenetic or hematologic relapse of the disease without the need for maintenance therapy could be achieved. ${ }^{45,46}$ However a thorough monitoring of minimal residual disease with qRT-PCR could demonstrate a presence of the BCR-ABL gene transcript even a long time after transplantation, which does not necessarily imply relapse, because no other signs of disease recurrence were observed. ${ }^{47,48}$ Apparently most of the patients were cured even though not all BCR-ABL positive leukemic cells were completely eradicated. A similar pattern is now observed in the course of the long-term follow-up of TKI-treated patients who eventually stop the treatment after achieving a deep and sustained molecular remission, and is a convincing illustration of the concept of „operational cure”. ${ }^{49}$ The first pilot study was initiated in 12 chronic phase CML patients treated with imatinib at a standard dose who have achieved and maintained a complete molecular response (CMR) for at least 2 years, which was assessed by qRT-PCR with a sensitivity ranging between a 4.5- and a 5-log reduction. After a median follow-up time of 18 months, $50 \%$ of patients remained off-therapy without reappearance of BCR-ABL transcripts. ${ }^{50}$ Those patients still have an undetectable level of BCR-ABL transcripts after a median follow-up time of 6 years (range, 4-8). The same entry criteria were used for the multicenter study entitled the "Stop Imatinib" (STIM) which enrolled prospectively one hundred patients. The treatment with imatinib was restarted in the case of molecular relapse, which was arbitrarily defined as 2 positive qRT-PCR results over a period of 1 month showing at least a 1 log increase in BCR-ABL transcripts. At 36 months the overall probability of molecular relapse-free, and treatment-free remission was 39\% (95\% CI, 29-48). Most patient relapsed within 6 months from imatinib cessation; 3 cases of late relapse occuring at months 19, 20, and 22, respectively were noted. Most patient form the pilot as well as from the STIM study remained responsive to retreatment with imatinib. The second French "Stop Imatinib" (STIM2) study used the same criteria as those for the STIM1. The molecular relapse was defined also in a similar way, and a loss of MMR detected at one point was a trigger of TKI retreatment. The median follow-up of 124 enrolled patients is 12 months (range 1-25). After discontinuation of imatinib, a molecular relapse occurred in 48 pts (most within 6 months form imatinib cessation; 3 relapses between 6 and 12 month), and 76 patients (61\%) were still free-of treatment at the last update. Forty one patients experienced a BCR-ABL transcript fluctuation in the qRT-PCR without clear molecular relapse. ${ }^{52}$ The TWISTER study is a prospective clinical trial which have used very similar as those in a STIM study entry and molecular relapse criteria for 40 chronic phase CML patients who discontinued imatinib. At 24 months, the proportion of patients remaining in stable treatment-free remission was $47.1 \%$. Most patients 
relapsed within 4 months of stopping imatinib, importantly, no relapses beyond 27 months were observed. ${ }^{53}$ Other report demonstrates the probability of maintaining the CMR at 1 year of $28,6 \%$ after discontinuation of imatinib in 14 chronic phase CML patients. None of the patients however was strictly in CMR throughout the entire 2-year period preceding cessation of imatinib and half of the patients were high risk according to the Sokal index. ${ }^{54} \mathrm{~A}$ nationwide survey conducted in Japan identified 50 patients who stopped imatinib for at least 6 months. Molecular relapse was detected in 19 out of 43 analyzed patients, and the CMR rate after imatinib discontinuation was estimated to be $47 \%{ }^{55}$ All mentioned above studies demonstrate the proof of concept for stopping imatinib in CML patients who were able to achieve a deep, sustained molecular response. It seems certain that an MMR is not enough to plan a discontinuation strategy. The STIM1 and STIM2 study used a 4.5 - 5-log reduction, and the TWISTER study used a 4.5-log reduction for their definition of CMR. Larger studies suggest that beside of the level of BCR-ABL transcripts after imatinib treatment, the duration of deep molecular response is of major importance in achievement of a long-term treatment-free survival. In the STIM1, STIM2 and TWISTER trials, a sustained CMR for at least 2 years was used as the criterion. ${ }^{51,52,53}$ In the multivariate analysis and logistical regression in the STIM1 study, Sokal risk and

\section{References:}

1. Deininger MW. Milestones and monitoring in patients with CML treated with imatinib. Education Program Book 419-426. 50th ASH Conference 2008

2. Schindler T, Bornmann W, Pellicena P, Miller WT, Clarkson B, Kuriyan J. Structural mechanism for STI-571 inhibition of Abelson tyrosine kinase. Science 2000; $289 \quad 1938-42$ http://dx.doi.org/10.1126/science.289.5486.1938 PMid:10988075

3. Buchdunger E, Zimmermann J, Mett H, Meyer T, Muller M, Druker BJ, and Lydon NB (1996) Inhibition of the Abl proteintyrosine kinase in vitro and in vivo by a 2-phenylaminopyrimidine derivative. Cancer Res1996; 56:100-104. PMid:8548747

4. Druker BJ, Tamura S, Buchdunger E, Ohno S, Segal GM, Fanning S, Zimmermann J, and Lydon NB (1996) Effects of a selective inhibitor of the Abl tyrosine kinase on the growth of Bcr-Abl positive cells. Nat Med1996; 2:561-566. http://dx.doi.org/10.1038/nm0596-561 PMid:8616716

5. Carroll M, Ohno Jones S, Tamura S, Buchdunger E, Zimmermann J, Lydon NB, Gilliland DG, and Druker B (1997) CGP 57148, a tyrosine kinase inhibitor, inhibits the growth of cells expressing BCR-ABL, TEL-ABL and TEL-PDGFR fusion proteins. Blood 1997;90:4947-4952. PMid:9389713

6. Deininger MWN and DRUKER BJ. Specific Targeted Therapy of Chronic Myelogenous Leukemia with Imatinib. Pharmacol Rev $2003 \quad$ 55:401-423. $\quad$ http://dx.doi.org/10.1124/pr.55.3.4 PMid:12869662

7. Druker BJ, Talpaz M, Resta DJ, Peng B, Buchdunger E, Ford JM, Lydon NB, Kantarjian H, Capdeville R, Ohno-Jones S, et al. Efficacy and safety of a specific inhibitor of the BCR-ABL tyrosine kinase in chronic myeloid leukemia. $\mathrm{N}$ Engl J Med 2001a;344 http://dx.doi.org/10.1056/NEJM200104053441401 PMid:11287972 imatinib therapy duration were confirmed as 2 independent prognostic factors for prediction of molecular relapse after imatinib discontinuation. ${ }^{51}$ It is obviously necessary to monitor regularly the minimal residual disease using qRT-PCR to allow an early detection of a fast molecular recurrence and restart the treatment as soon as possible. Most of the molecular recurrences occurred within the first few months of imatinib cessation. The presence of residual BCR-ABL positive cells in CML patients in CMR before and after imatinib discontinuation were demonstrated by Ross et al. who used genomic DNA-based PCR, which allows to detect rearranged BCR-ABL gene at a level of around 1- to 2-log below the detection limit of conventional (mRNA) qRT-PCR. However, there was no link between detection of BCR-ABL by genomic DNA-based PCR and relapse. ${ }^{53}$ Monitoring of residual disease by more sensitive conventional qRT-PCR within STIM1 study also does not allow the prediction of relapse after imatinib cessation. ${ }^{51}$ Importantly some fluctuations in BCR-ABL levels detected by conventional qRT-PCR method (in 33\% patients in STIM2 study) could be observed after discontinuation without confirmation of a molecular relapse. 41 patients (33\%) in STIM2 study experienced a BCRABL qRT-PCR fluctuation without molecular relapse, confirming that BCR-ABL reappearance does not mean automatically clinical relapse and reinforcing the concept of "operational cure". 52,49

8. Druker BJ, Sawyers CL, Kantarjian H, Resta DJ, Reese SF, Ford JM, Capdeville R, and Talpaz M. Activity of a specific inhibitor of the BCR-ABL tyrosine kinase in the blast crisis of chronic myeloid leukemia and acute lymphoblastic leukemia with the Philadelphia chromosome. N Engl J Med 2001b; 344:1038-1042. http://dx.doi.org/10.1056/NEJM200104053441402 PMid:11287973

9. Sawyers CL, Hochhaus A, Feldman E, Goldman JM, Miller CB, Ottmann OG, Schiffer CA, Talpaz M, Guilhot F, Deininger MW, et al. Imatinib induces hematologic and cytogenetic responses in patients with chronic myelogenous leukemia in myeloid blast crisis: results of a phase II study. Blood 2002 ;99 :3530-3539. http://dx.doi.org/10.1182/blood.V99.10.3530 PMid:11986204

10. Ottmann OG, Druker BJ, Sawyers CL, Goldman JM, Reiffers J, Silver RT, Tura S, Fischer T, Deininger MW, Schiffer CA, et al. A phase 2 study of imatinib in patients with relapsed or refractory Philadelphia chromosome-positive acute lymphoid leukemias. Blood 2002 ;100 :1965-1971 http://dx.doi.org/10.1182/blood-200112-0181 PMid:12200353

11. Talpaz M, Silver RT, Druker BJ, Goldman JM, GambacortiPasserini C, Guilhot F, Schiffer CA, Fischer T, Deininger MW, Lennard AL, et al. Imatinib induces durable hematologic and cytogenetic responses in patients with accelerated phase chronic myeloid leukemia: results of a phase 2 study. Blood 2002 ; 99 :1928-1937. http://dx.doi.org/10.1182/blood.V99.6.1928 PMid:11877262

12. O’Brien SG, Guilhot F, Larson RA, et al. Imatinib compared with interferon and low-dose cytarabine for newly diagnosed chronicphase chronic myeloid leukemia. $N$ Engl $J$ Med. 2003 ;348(11):994-1004.

http://dx.doi.org/10.1056/NEJMoa022457 PMid:12637609

13. Druker BJ, Guilhot F, O’Brien SG, et al. Five-year follow-up of 
patients receiving imatinib for chronic myeloid leukemia. N Engl J Med. 2006;355(23): 2408-2417.

http://dx.doi.org/10.1056/NEJMoa062867 PMid:17151364

14. Hochhaus A, O’Brien SG, Guilhot F, et al. Six year follow-up of patients receiving imatinib for the first-line treatment of chronic myeloid leukemia. Leukemia. 2009;23(6):1054-1061. http://dx.doi.org/10.1038/leu.2009.38 PMid:19282833

15. O’Brien SG, Guilhot F, Goldman JM, et al. International randomized study of interferon versus STI571 (IRIS) 7-year follow-up: sustained survival, low rate of transformation and increased rate of major molecular response (MMR) in patients (pts) with newly diagnosed chronic myeloid leukemia in chronic phase (CML-CP) treated with Imatinib (IM) [abstract]. Blood. 2008;112(11):76. Abstract 186.

16. Deininger M, O'Brien SG, Guilhot F, Goldman JM, Hochhaus A, Hughes TP, Radich JP, Hatfield AK, Mone M, Filian J, Reynolds J, Gathmann I, Larson RA, and Druker BJ. International Randomized Study of Interferon Vs STI571 (IRIS) 8-Year Follow up: Sustained Survival and Low Risk for Progression or Events in Patients with Newly Diagnosed Chronic Myeloid Leukemia in Chronic Phase (CML-CP) Treated with Imatinib. Blood 2009 ; ASH Abstract: 1126

17. Hughes T, Branford S. Molecular monitoring of BCR-ABL as a guide to clinical management in chronic myeloid leukaemia. Blood Rev. 2006; 20(1):29-41. http://dx.doi.org/10.1016/j.blre.2005.01.008 PMid:16426942

18. Peng B, Lloyd P, Schran H. Clinical pharmacokinetics of imatinib. Clin Pharmacokinet. 2005; 444:879-894. http://dx.doi.org/10.2165/00003088-200544090-00001 PMid:16122278

19. Peng BM, Hayes M, Resta D, et al. Pharmacokinetics and pharmacodynamics of imatinib in a phase I trial with chronic myeloid leukemia patients. J Clin Oncol. 2004;22:935-942. http://dx.doi.org/10.1200/JC0.2004.03.050 PMid:14990650

20. Larson RA, Druker BJ, Guilhot F, O'Brien SG, Riviere GJ, Krahnke T, Gathmann I, Wang Y and for the IRIS (International Randomized Interferon vs STI571). Study Group Imatinib pharmacokinetics and its correlation with response and safety in chronic-phase chronic myeloid leukemia: a subanalysis of the IRIS study Blood. 2008;111: 4022-4028 http://dx.doi.org/10.1182/blood-2007-10-116475 PMid:18256322

21. Cervantes F, Lopez-Garrido P, Montero MI, et al. Early intervention during imatinib therapy on patients with newly diagnosed chronic-phase chronic myeloid leukemia: a study of the Spanish PETHEMA group. Haematologica. 2010;95(8):1317-1324. http://dx.doi.org/10.3324/haematol.2009.021154 PMid:20220063 PMCid:PMC2913080

22. Preudhomme C, Guilhot J, Nicolini FE, Guerci-Bresler A, RigalHuguet F, Maloisel F, Coiteux V, Gardembas M, Berthou C, Vekhoff A, Rea D, Jourdan E, Allard C, Delmer A, Rousselot P, Legros L, Berger M, Corm S, Etienne G, Roche-Lestienne C, Eclache V, Mahon FX, Guilhot F; SPIRIT Investigators; France Intergroupe des Leucémies Myéloïdes Chroniques (Fi-LMC). Imatinib plus peginterferon alfa-2a in chronic myeloid leukemia. N Engl J Med. 2010;363 (26) :2511-2521. http://dx.doi.org/10.1056/NEJMoa1004095 PMid:21175313

23. Gugliotta G, Castagnetti F, Palandri F, et al. Frontline imatinib treatment of chronic myeloid leukemia: no impact of age on outcome, a survey by the GIMEMA CML Working Party. Blood. 2011;117(21):5591-5599. http://dx.doi.org/10.1182/blood-201012-324228 PMid:21450900

24. Faber E, Muzik J, Koza V, et al. Treatment of consecutive patients with chronic myeloid leukaemia in the cooperating centres from the Czech Republic and the whole of Slovakia after 2002 - a report from the population-based CAMELIA registry. Eur J Haematol. 2011;87(2):157-168 0609.2011.01637.x PMid:21535160

25. Hehlmann R, Lauseker M, Jung-Munkwitz S, Leitner A, Muller MC, Pletsch N, Proetel U, Haferlach C, Schlegelberger B, Balleisen L, Hanel M, P?rrmann M, Krause SW, Nerl C, Pralle H, Gratwohl A, Hossfeld DK, Hasford J, Hochhaus A, and Saußele S. Tolerability-Adapted Imatinib $800 \mathrm{mg} / \mathrm{d}$ Versus $400 \mathrm{mg} / \mathrm{d}$ Versus $400 \mathrm{mg} / \mathrm{d}$ Plus Interferon-alpha in Newly Diagnosed Chronic Myeloid Leukemia. JCO 2011; http://dx.doi.org/10.1200/JCO.2010.32.0598
26. Kim DW, Goh HG, Kim SH, et al. Comprehensive therapeutic outcomes of frontline imatinib mesylate in newly diagnosed chronic phase chronic myeloid leukemia patients in Korea: feasibility assessment of current ELN recommendations. Intern J Hematol. 2012;96(1):47-57. http://dx.doi.org/10.1007/s12185-0121093-y PMid:22610512

27. Radich JP, Kopecky KJ, Appelbaum FR, et al. A randomized trial of dasatinib $100 \mathrm{mg}$ versus imatinib $400 \mathrm{mg}$ in newly diagnosed chronic-phase chronic myeloid leukemia. Blood. 2012;120(19):3898-3905. http://dx.doi.org/10.1182/blood-201202-410688 PMid:22915637 PMCid:PMC3496952

28. Cortes JE, Kim DW, Kantarjian HM, et al. Bosutinib versus imatinib in newly diagnosed chronic phase chronic myeloid leukemia: results from the BELA trial. J Clin Oncol. 2012;30(28):3486-3492.

http://dx.doi.org/10.1200/JCO.2011.38.7522 PMid:22949154

29. Saglio G, Kim DW, Issaragrisil S, et al. Nilotinib versus imatinib for newly diagnosed chronic myeloid leukemia. N Engl J Med. 2010;362(24):2251-9. http://dx.doi.org/10.1056/NEJMoa0912614 PMid:20525993

30. Kantarjian HM, Hochhaus A, Saglio G, et al. Nilotinib versus imatinib for the treatment of patients with newly diagnosed chronic phase, Philadlephia chromosome-positive, chronic myeloid leukemia: 24-month minimum follow-up of the phase 3 randomised ENESTnd trial. Lancet Oncol. 2011;12(9):841-851. http://dx.doi.org/10.1016/S1470-2045(11)70201-7

31. Larson RA, Hochhaus A, Hughes TP, et al. Nilotinib vs imatinib in patients with newly diagnosed Philadelphia chromosome-positive chronic myeloid leukemia in chronic phase: ENESTnd 3-year follow-up. Leukemia. 2012;26(10):2197-203. http://dx.doi.org/10.1038/leu.2012.134 PMid:22699418

32. Kantarjian H, Shah NP, Hochhaus A, et al. Dasatinib versus imatinib in newly diagnosed chronic phase chronic myeloid leukemia. N Engl J Med. 2010;362(24):2260-2270. http://dx.doi.org/10.1056/NEJMoa1002315 PMid:20525995

33. Kantarjian HM, Shah NP, Cortes JE et al. Dasatinib or imatinib in newly diagnosed chronic-phase chronic myeloid leukemia: 2-year follow-up from a randomized phase 3 trial (DASISION). Blood. 2012;119(5):1123-1129. http://dx.doi.org/10.1182/blood-2011-08376087 PMid:22160483

34. Weisberg E, Griffin JD. Mechanism of resistance to the ABL tyrosine kinase inhibitor STI571 in BCR-ABL-transformed hematopoietic cell lines. Blood. 2000;95:3498-3505. PMid:10828035

35. Mahon FX, Deininger MW, Schultheis B, et al. Selection and characterization of BCR-ABL positive cell lines with differential sensitivity to the tyrosine kinase inhibitor STI571: diverse mechanisms of resistance. Blood. 2000;96:1070-1079. PMid:10910924

36. le Coutre P, Tassi E, Varella-Garcia M, et al. Induction of resistance to the Abelson inhibitor STI571 in human leukemic cells through gene amplification. Blood. 2000;95:1758-1766. PMid:10688835

37. Kantarjian H, Talpaz M, O'Brien S, Garcia-Manero G, Verstovsek S, Giles F, Rios MB, Shan J, Letvak L, Thomas D, Faderl S, Ferrajoli A and Cortes J. High-dose imatinib mesylate therapy in newly diagnosed Philadelphia chromosome -positive chronic phase chronic myeloid leukemia. Blood; 2004 103: 2873-2878 http://dx.doi.org/10.1182/blood-2003-11-3800 PMid:15070658

38. Baccarani M, Rosti G, Castagnetti F,Haznedaroglu I, Porkka K, Abruzzese E, Alimena G, Ehrencrona H,Hjorth-Hansen H, Kairisto V, Levato L, Martinelli G, Nagler A, Lanng Nielsen J, Ozbek U, Palandri F, Palmieri F, Pane F, Rege-Cambrin G, Russo D, Specchia G, Testoni N, Weiss-Bjerrum O, Saglio G, and Simonsson B. Comparison of imatinib $400 \mathrm{mg}$ and $800 \mathrm{mg}$ daily in the front-line treatment of high-risk, Philadelphia-positive chronic myeloid leukemia: a European LeukemiaNet Study. Blood 2009 113: 4497-4504 http://dx.doi.org/10.1182/blood-2008-12-191254 PMid:19264678

39. Andreas AP, Wolf DW, Fong DF, et al. High doses of imatinib mesylate ( $800 \mathrm{mg} /$ day) significantly improve rates of major and complete cytogenetic remissions (MCR, CCR) - results from the first planned interim analysis of a multicenter, randomised, 2 arm phase III study comparing imatinib standard dose (400 mg/day) with imatinib high dose [abstract]. Haematologica. 
2008;93(suppl):162. Abstract 0406

40. Cortes JG, Baccarani M, Guilhot F, et al. First report of the TOPS study: a randomized phase III trial of $400 \mathrm{mg}$ vs $800 \mathrm{mg}$ imatinib in patients with newly diagnosed, previously untreated CML in chronic phase using molecular endpoints [abstract]. Haematologica. 2008;93(suppl):160. Abstract 0402.

41. Hehlmann R, Saussele S, Lauseker M, Proetel U, Kovalevskaya E, Leitner A, Haferlach C, Schlegelberger B, Müller MC, Hanfstein B, Pfirrmann M, Ehninger G, Fischer T, Hasford J, Hochhaus A, Hossfeld DK, Kolb HJ, Krause SW, Nerl C, Pralle H, Gratwohl A, Tobler A, Heimpel H, and The German CML Study Group. Randomized Comparison of Imatinib 400 Mg Vs. Imatinib + IFN Vs. Imatinib + AraC Vs. Imatinib after IFN Vs. Imatinib 800 Mg: Optimized Treatment and Survival. Designed First Interim Analysis of the German CML Study IV. Blood. 2008 ; abst 184.

42. Johnson-Ansah H, Guilhot J, Rousselot P, Rea D, Legros L, RigalHuguet F, Nicolini FE, Mahon FX, Preudhomme C, Guilhot F. Tolerability and efficacy of pegylated interferon-a-2a in combination with imatinib for patients with chronic-phase chronic myeloid leukemia. Cancer. 2013 Sep 16. http://dx.doi.org/10.1002/cncr.28328

43. Simonsson B, Gedde-Dahl T, Markevarn B, et al. Combination of pegylated IFN-_2b with imatinib increases molecular response rates in patients with low- or intermediate-risk chronic myeloid leukemia. Blood. 2011;118(12):3228-3235 http://dx.doi.org/10.1182/blood-2011-02-336685 PMid:21685374

44. Cortes J, Quintas-Cardama A, Jones D, et al. A randomized trial of front-line high dose imatinib mesylate with or without pegylated interferon alpha-2b and granulocyte-macrophage colony stimulating factor. Cancer. 2011;117(3):572-580. http://dx.doi.org/10.1002/cncr.25438 PMid:20886606

45. Mahon FX, Fort MP, Etienne G, et al. Interferon alpha alone is able to cure chronic myeloid leukemia in a small subset of patients despite the persistence of leukemic cells: experience of long follow up after treatment discontinuation [abstract]. Blood (ASH Annual Meeting Abstracts). 2010;116:2299.

46. van Rhee F, Szydlo RM, Hermans J, et al. Long term results after allogeneic transplantation for chronic myelogenous leukemia in chronic phase: a report from the chronic leukemia working party of the European group for blood and marrow transplantation. Bone Marrow Transplant. 1997;20:553-560. http://dx.doi.org/10.1038/sj.bmt.1700933 PMid:9337056

47. Kaeda J, O’Shea D, Szydlo RM, et al. Serial measurement of BCRABL transcripts in the peripheral blood after allogeneic stem cell transplantation for chronic myeloid leukemia: an attempt to define patients who may not require further therapy. Blood.
2006;107:4171-4176. http://dx.doi.org/10.1182/blood-2005-083320 PMid:16449534 PMCid:PMC1895293

48. Radich JP, Gooley T, Bryant E, et al. The significance of bcr-ab molecular detection in chronic myeloid leukemia patients "late," 18 months or more after transplantation. Blood.2001;98:1701-1707. http://dx.doi.org/10.1182/blood.V98.6.1701 PMid:11535500

49. Goldman J, Gordon M. Why do chronic myelogenous leukemia stem cells survive allogeneic stem cell transplantation or imatinib: does it really matter? Leuk Lymphoma. 2006;47:1-7. http://dx.doi.org/10.1080/10428190500407996 PMid:16321820

50. Rousselot P, Huguet F, Rea D, et al. Imatinib mesylate discontinuation in patients with chronic myelogenous leukemia in complete molecular remission for more than 2 years. Blood. 2007;109:58-60. http://dx.doi.org/10.1182/blood-2006-03-011239 PMid:16973963

51. Mahon FX, Rea D, Guilhot J, et al. Discontinuation of imatinib in patients with chronic myeloid leukaemia who have maintained complete molecular remission for at least 2 years: the prospective, multicentre, Stop IMatinib (STIM) trial. Lancet Oncol. 2010;11:1029-1035. http://dx.doi.org/10.1016/S14702045(10)70233-3

52. Mahon FX, Nicolini FE, Noël MP, Escoffre M, Charbonnier A, Rea D, Dubruille V, Varet BR, Legros L, Guerci A, Etienne G, Guilhot F, Dulucq S, PharmD, Rousselot P, and Guilhot J. Preliminary Report Of The STIM2 Study: A Multicenter Stop Imatinib Trial For Chronic Phase Chronic Myeloid Leukemia De Novo Patients On Imatinib. Blood 2013 ASH Annual Meeting, Abstract 654

53. Ross DM, Branford S, Seymour JF, Schwarer AP, Arthur C, Yeung DT, Dang P, Goyne JM, Slader C, Filshie RJ, Mills AK, Melo JV, White DL, Grigg AP, Hughes TP. Safety and efficacy of imatinib cessation for CML patients with stable undetectable minimal residual disease: results from the TWISTER study. Blood. 2013 Jul 25;122(4):515-22. $\quad$ http://dx.doi.org/10.1182/blood-2013-02483750 PMid:23704092

54. Yhim HY, Lee NR, Song EK, et al. Imatinib mesylate discontinuation in patients with chronic myeloid leukemia who have received front-line imatinib mesylate therapy and achieved complete molecular response. Leuk Res. 2012;36:689-693. http://dx.doi.org/10.1016/j.leukres.2012.02.011 PMid:22398220

55. Takahashi N, Kyo T, Maeda Y, et al. Discontinuation of imatinib in Japanese patients with chronic myeloid leukemia. Haematologica. 2012;97(6):903-906. http://dx.doi.org/10.3324/haematol.2011.056853 PMid:22180435 PMCid:PMC3366657 